\title{
Distribution and Diversity of White Grub Species in Western Maharashtra, India
}

\author{
Rahul B. Gite ${ }^{1}$, Pandurang B. Mohite ${ }^{2}$, Balkrishna Rathour ${ }^{3}$ \\ Division of Agril. Entomology, College of Agriculture, Kolhapur-416004 (M.S.), India
}

\begin{abstract}
The present work provides information on distribution of white grub species from four districts of Western Maharashtra viz. Sangli, Satara, Solapur and Kolhapur. A total of 16 species were recorded during the study period under eight genera distributed in three sub families viz., Melolonthinae, Rutelinae, Dynastinae and five tribes. The species Adoretus versutus, Anomala ruficapilla, Sophrops karschi was newly recorded in Western Maharashtra. The single dominant species, Holotrichia serrata was observed up to 26.55 per cent of all individuals followed by was Phyllognathus dionysius with abundance of 16.58 per cent and 15.20 per cent, respectively. The lowest abundance was observed in species Anomala ruficapilla (0.23 per cent).
\end{abstract}

Keywords: White grub, Distribution, Abundance, Diversity

\section{Introduction}

White grubs (Coleoptera: Scarabaeidae) are the soil inhibiting and root feeding immature stages of scarab beetles of which larval stage is destructive in nature (Theurkar, 2013). The white grub's family is second largest family which includes over 30,000 species (Khanal et al. 2012). Near about 300 species of white grub were recorded from India (Bhawane et al. 2011). White grubs are broad, fleshy, whitish or grayish white and the body is curved in the form of ' $C$ ' shape. Most of the white grubs especially from the sub-family Melolonthinae are most destructive and troublesome soil insects in many parts to certain endemics pockets in the states of Rajasthan, Uttar Pradesh, Gujarat, Maharashtra and Karnataka (Bhawane et al. 2012).

The larvae of white grub associated with number of crops and causes economic damage. The damage caused by white grub larvae was estimated to reduce the crop yield by about 40-80 per cent and in more recent study by about $12-60$ per cent. Until recently three main genera viz., Phylophaga sp., Holotrichia spp. and Anomala sp. were reported to be major pest in Nepal (Khanal et al. 2012). In Kolhapur district of India, Leucopholis lepidophora Blanch is serious phytophagous pest damaging mainly sugarcane crop located along the bank of rivers of Western Maharashtra. Besides Holotrichia serrata, H. fissa, H. karschi and Phyllognathus dionysius also attained the pest status in field of paddy, jowar, maize, turmeric and tobacco (Bhawane et al. 2012). The common economically important species of white grubs found in India are $H$. consanguinea, $H$. insularis, $H$. serrata, Leucopholis lepidophora, L. cornephora, Anomala benghalensis, Oryctes rhinocerous, Phyllognathus dionysius, Oxycetonia versicolor viz. In Maharashtra this pest has become serious problem in Kolhapur, Sangli, Satara, Solapur, Ahmednagar, Buldhana, Dhule, Jalgaon, Nanded, Osmanabad, Parbhani, Beed, Wardha and some part of Pune district. The white grubs becoming very serious threat in sugarcane cultivation in Western Maharashtra viz., Sangali, Satara, Solapur and Kolhapur districts (Bhawane et al. 2011). The present study aimed to clarify the uncertainties of species identity and distribution.

\section{Material and Methods}

\section{Selection of sampling sites:}

Four districts of Western Maharashtra viz., Sangli, Satara, Solapur and Kolhapur were selected for collection of white grubs on the basis of cropping pattern and presence of host trees near the roadside. The collection of beetles was carried out after receiving first showers of rain. The beetles were collected from host trees like neem (Azadirachta indica), Wild ber (Zizyphs sp.), babhul (Acacia arabica) and khair (Acacia catechu) viz., located on roadside and from commercial growing crops.

\section{Collection of the beetles from selected sites:}

The scarab beetles were comes out from soil at dusk time, 6:45 pm to $10 \mathrm{pm}$ for feeding and mating purpose on onset of rains. Considering this period, the host trees commonly found on roadsides and around infested fields were surveyed and beetles were collected for further study. The collection of beetles was undertaken by following techniques:-

a) Use of light traps

b) Hand collection during emergence

c) Collection of the grubs and rearing

The grubs were collected from the farmer's field at different locations of Western Maharashtra. The collected grubs were reared up to adult stage under laboratory conditions and beetles were collected and sent for identification.

\section{Estimation of the population:}

The estimation of the population was done by counting the population of grubs and adults. The population of the different species was estimated from the adults collected in the light traps installed at different locations and hand collection method.

The collected data were employed for the statistical analysis to calculate species diversity and abundance by applying Simpson's diversity index as suggested by Biranvand et al. (2014). Simpson's index (D) is a measure of diversity. The formula for calculating $\mathrm{D}$ is presented as:

$$
\mathrm{D}=\frac{\sum \mathrm{n}(\mathrm{n}-1)}{\mathrm{N}(\mathrm{N}-1)}
$$




\section{International Journal of Science and Research (IJSR) \\ ISSN (Online): 2319-7064 \\ Index Copernicus Value (2013): 6.14 | Impact Factor (2014): 5.611}

Where $\mathrm{n}=$ the total number of organisms of each individual species, $\mathrm{N}=$ the total number of organisms of all species and $1-\mathrm{D}=$ Simpson's diversity index, $1 / \mathrm{D}=$ Simpson's reciprocal index.

The value of $\mathrm{D}$ ranges from 0 to 1 . With this index, 0 represents infinite diversity and 1 no diversity. That is, the bigger value shows lower diversity. This does not seem intuitive or logical, so some texts use derivations of the index, such as the inverse (1/D) or the difference from 1 (1D).

\section{Results and Discussion}

1. Distribution and abundance of White Grubs in Western Maharashtra:

A total of 16 species were recorded during the study period under eight genera distributed in three sub families viz., Melolonthinae, Rutelinae, Dynastinae and five tribes. The collected beetles were identified at All India Network Project on White Grubs and Other Soil Arthropds, Banglore, Karnataka. The results show that beetle emergence was started after receiving first pre monsoon showers in May and June month onwards. The present findings were in conformity with the results of Kumar et al. (2009) and Shivanna et al. (2014). Among all the genera, Holotrichia was found to be most abundant and dominant. The results were in agreement with Theurkar et al. (2013). The species
Adoretus versutus, Anomala ruficapilla, Sophrops karschi was newly observed in Western Maharashtra. The white grub species Leucopholis lepidophora was observed to cause damage to sugarcane near the rivers bank of Western Maharashtra.

The single dominant species Holotrichia serrata was observed up to 26.55 per cent of all individuals followed by Phyllognathus dionysius and L. lepidophora with abundance of 16.58 per cent and 15.20 per cent, respectively. The lowest abundance was observed in species Anomala ruficapilla (0.23 per cent)

\section{Diversity of white grubs in Western Maharashtra:}

The diversity of white grub was studied for the population collected in different districts of Western Maharashtra viz., Sangli, Satara, Solapur and Kolhapur. Diversity and reciprocal index were calculated by Simpson's index (Biravand et al. 2014). This index considers both the number and distribution of the species. The Simpson's index was 0.15 and the Simpson's index of diversity for Western Maharashtra was 0.85 . The 0.85 Simpson's diversity index shows high species diversity. The value of Simpson's Index of Diversity ranges between 0 and 1, greater the value greater the sample diversity. The diversity of white grubs by Simpson's method is presented in Table 3.

Table 1: District wise distribution and relative abundance of White Grub in Western Maharashtra

\begin{tabular}{|c|c|c|c|c|c|c|}
\hline \multirow[t]{2}{*}{ Sr. No. } & Districts & \multirow{2}{*}{ Sangli } & \multirow{2}{*}{ Satara } & \multirow{2}{*}{ Kolhapur } & \multirow{2}{*}{ Solapur } & \multirow{2}{*}{ Total } \\
\hline & Species & & & & & \\
\hline 1 & Holotrichia serrata (Fabricius) & $\begin{array}{c}350 \\
(13.62) \\
\end{array}$ & $\begin{array}{c}348 \\
(55.23) \\
\end{array}$ & $\begin{array}{c}455 \\
(22.06) \\
\end{array}$ & $\begin{array}{c}405 \\
(66.72) \\
\end{array}$ & $\begin{array}{c}1558 \\
(26.55) \\
\end{array}$ \\
\hline 2 & Holotrichia rufloflava (Brenske) & - & $\begin{array}{c}10 \\
(1.58) \\
\end{array}$ & $\begin{array}{c}8 \\
(0.38) \\
\end{array}$ & $\begin{array}{c}9 \\
(1.48) \\
\end{array}$ & $\begin{array}{c}27 \\
(0.46)\end{array}$ \\
\hline 3 & Holotrichia consanguinea (Blanchard) & $\begin{array}{c}280 \\
(10.90) \\
\end{array}$ & - & $\begin{array}{c}450 \\
(21.82) \\
\end{array}$ & - & $\begin{array}{c}730 \\
(12.44) \\
\end{array}$ \\
\hline 4 & Holotrichia spp. & $\begin{array}{c}156 \\
(6.07) \\
\end{array}$ & - & $\begin{array}{c}164 \\
(7.95) \\
\end{array}$ & - & $\begin{array}{c}320 \\
(5.45) \\
\end{array}$ \\
\hline 5 & Anomalochela sp. & - & - & $\begin{array}{c}312 \\
(1.51) \\
\end{array}$ & - & $\begin{array}{c}312 \\
(5.31) \\
\end{array}$ \\
\hline 6 & Adoretus versutus (Harold) & - & - & $\begin{array}{c}17 \\
(0.82) \\
\end{array}$ & - & $\begin{array}{c}17 \\
(0.28)\end{array}$ \\
\hline 7 & Apogonia sp. 1 & - & - & $\begin{array}{c}127 \\
(6.15) \\
\end{array}$ & - & $\begin{array}{c}127 \\
(2.16) \\
\end{array}$ \\
\hline 8 & Apogonia sp. 2 & - & - & $\begin{array}{c}136 \\
(6.59)\end{array}$ & - & $\begin{array}{c}136 \\
(2.31)\end{array}$ \\
\hline 9 & Phyllognathus dionysius (Fabricius) & $\begin{array}{c}780 \\
(30.37) \\
\end{array}$ & - & - & $\begin{array}{c}193 \\
(31.79) \\
\end{array}$ & $\begin{array}{c}973 \\
(16.58)\end{array}$ \\
\hline 10 & Anomala bengalensis (Blanchard) & $\begin{array}{c}622 \\
(24.22) \\
\end{array}$ & - & - & - & $\begin{array}{c}622 \\
(10.60) \\
\end{array}$ \\
\hline 11 & $\begin{array}{l}\text { Holotrichia nagpurensis (Khan and } \\
\text { Ghai) }\end{array}$ & - & - & $\begin{array}{c}67 \\
(3.24) \\
\end{array}$ & - & $\begin{array}{c}67 \\
(1.14)\end{array}$ \\
\hline 12 & Anomala dorsalis (Fabricius) & - & - & $\begin{array}{c}27 \\
(1.30) \\
\end{array}$ & - & $\begin{array}{c}27 \\
(0.46) \\
\end{array}$ \\
\hline 13 & Anomala ruficapilla (Burmeister) & - & - & $\begin{array}{c}14 \\
(0.67)\end{array}$ & - & $\begin{array}{c}14 \\
(0.23)\end{array}$ \\
\hline 14 & Sophrops sp. 1 & - & - & $\begin{array}{c}27 \\
(1.30) \\
\end{array}$ & - & $\begin{array}{c}27 \\
(0.46) \\
\end{array}$ \\
\hline 15 & Sophrops karschi (Brenske) & - & - & $\begin{array}{c}18 \\
(0.87) \\
\end{array}$ & - & $\begin{array}{c}18 \\
(0.30) \\
\end{array}$ \\
\hline 16 & Leucopholis lepidophora (Blanchard) & $\begin{array}{c}380 \\
(14.79)\end{array}$ & $\begin{array}{c}272 \\
(43.17)\end{array}$ & $\begin{array}{c}240 \\
(11.63)\end{array}$ & - & $\begin{array}{c}892 \\
(15.20) \\
\end{array}$ \\
\hline & Total & 2568 & 630 & 2062 & 607 & 5867 \\
\hline
\end{tabular}

Volume 4 Issue 12, December 2015 


\section{International Journal of Science and Research (IJSR) \\ ISSN (Online): 2319-7064}

Index Copernicus Value (2013): 6.14 | Impact Factor (2014): 5.611

* Values in parenthesis shows relative abundance of species in per cent

Table 2: Diversity of White Grub by Simpson's method

\begin{tabular}{|c|l|c|c|c|}
\hline $\begin{array}{c}\text { Sr. } \\
\text { No. }\end{array}$ & \multicolumn{1}{|c|}{ White Grub Species } & $\begin{array}{c}\text { Number of } \\
\text { specimens (n) }\end{array}$ & $\mathrm{n}(\mathrm{n}-1)$ & $\begin{array}{c}\text { Simpson's Index } \\
\text { (D) }\end{array}$ \\
\hline 1 & Holotrichia serrata (Fabricius) & 1558 & 2425806 & 702 \\
\hline 2 & Holotrichia rufloflava (Brenske) & 27 & 532170 \\
\hline 3 & Holotrichia consanguinea (Blanchard) & 730 & 102080 \\
\hline 4 & Holotrichia spp. & 320 & 97032 \\
\hline 5 & Anomalochela sp. & 312 & 272 \\
\hline 6 & Adoretus versutus (Harold) & 17 & 16002 \\
\hline 7 & Apogonia sp. 1 & 127 & 18360 \\
\hline 8 & Apogonia sp. 2 & 136 & 945756 \\
\hline 9 & Phyllognathus dionysius (Fabricius) & 973 & 386262 \\
\hline 10 & Anomala bengalensis (Blanchard) & 622 & 4422 \\
\hline 11 & Holotrichia nagpurensis (Khan and Ghai) & 67 & 702 \\
\hline 12 & Anomala dorsalis (Fabricius) & 27 & 182 \\
\hline 13 & Anomala ruficapilla (Burmeister) & 14 & 702 \\
\hline 14 & Sophrops sp. 1 & 27 & 306 \\
\hline 15 & Sophrops karschi (Brenske) & 18 & 794772 \\
\hline 16 & Leuchopholis lepidophora (Blanchard) & 892 & 5325528 \\
\hline & $\quad$ Total & 5867 & \\
\hline
\end{tabular}

Table 3: Simpson's diversity indices of White Grubs in examined region

\begin{tabular}{|c|c|}
\hline Region of sampling & \multirow{2}{*}{ Western Maharashtra } \\
\hline Index of diversity & \\
\hline Simpson's Index (D) & 0.15 \\
\hline Simpsons diversity index ( 1-D) & 0.85 \\
\hline Simpsons reciprocal index (1/D) & 6.66 \\
\hline
\end{tabular}

\section{Acknowledgement}

Authors are thankful to Dr. A.R.V. Kumar, Professor of Entomology, University of Agricultural Science, G. K. V. $\mathrm{K}$., Bangalore for identifying white grub species.

\section{References}

[1] Bhawane, G. P., Gaikwad, S. M., Mamlayya, A. B. and Aland, S.R. 2011. Life cycle of Holotrichia Karschi (Coleoptera: Scarabedae : Melolonthinae). The Bioscan, 6 (3): 471-474.

[2] Bhawane, G. P., Mamlayya, A. B., Wagh, S. R. and Chaugule, A. K. 2012. Diversity of white grub beetles and their host range from Northern Western Ghats, Kolhapur district, (MS) India. The Bioscan, 7 (4): 589596.

[3] Biravand, A., Jafari, R. and Khormizi, M. Z. 2014. Diversity and distribution of Coccinellidae in Lorestan Province, Iran. Biodiversity Journal, 5(1): 3-8.

[4] Khanal, D., Dhoj, Y., Sporleder, M. and Thapa, R. B. 2012. Distribution of white grubs in three ecological domains of Nepal. The Journal of Agriculture and Environment, Vol:13.

[5] Kumar, S., Sankar, M., Sethuramana, V. and Musthak, A. 2009. Population dynamics of white grubs (Coleoptera: Scarabaeidae) in the rose environment of Northern Bangalore, India. Indian J. Sci. and Tech., Vol. 2 (1).

[6] Theurkar, S., Patil, S. B., Ghadage, M. K., Zaware, Y. B. and Madan S. S. 2013. Distribution and abundance of white grubs (Coleoptera: Scarabaeidae) in Khed Taluka, part of Northern Western Ghats, MS, India. I. Res. J. Biological Sci., Vol. 1(7): 1-6. 